\title{
EVALUASI PERSYARATAN TERMAL BERDASARKAN REGULASI TENTANG KUALITAS UDARA
}

\author{
Ihsan Supono \\ Fakultas Teknik, Universitas Pamulang, Tangerang Selatan Banten \\ dosen01232@unpam.ac.id
}

\begin{abstract}
ABSTRAK
Dalam tulisan ini, akan disajikan suatu hasil evaluasi kualitas ruang kelas berdasarkan kondisi termalnya. Baku mutu tentang kondisi termal ruangan yang diacu dalam tulisan ini adalah suatu regulasi persyaratan kenyamanan termal. Metode yang digunakan dalam evaluasi adalah pengukuran langsung di dalam ruang kelas yang sedang digunakan dalam kegiatan belajar-mengajar. Analisis dilakukan berdasarkan perbandingan antara hasil pengukuran lapangan dengan baku mutu. Kesesuaian akan menjadi dasar untuk mencari peluang tindakan perbaikan yang dapat dilakukan pada ruangan tersebut. Sebaliknya, ketidaksesuaian yang terjadi akan menjadi dasar rekomendasi tindakan koreksi yang dapat dilakukan. Hasil evaluasi ini bersifat unik karena merupakan hasil pengukuran lapangan pada ruang kelas yang efektif dipergunakan. Kondisi cuaca secara umum, kondisi struktur bangunan, serta aktivitas dalam ruangan menjadi faktor yang dipertimbangkan dalam analisis. Hasil analisis menunjukkan bahwa ruangan dengan karakteristik struktur tidak permanen, memiliki kondisi udara yang tidak sesuai dengan karena temperatur ruang berada $2,5^{\circ} \mathrm{C}$ s.d $7,3^{\circ} \mathrm{C}$ diatas persyaratan. Sementara itu, kondisi kelembaban masih dalam batas yang diperbolehkan oleh persyaratan.
\end{abstract}

Kata kunci : kondisi kenyamanan termal, kualitas udara, temperatur dan kelembaban ruang

\section{PENDAHULUAN}

Kenyamanan termal, sampai tingkat tertentu, sangat penting untuk setiap individu karena mereka membutuhkan kondisi termal yang nyaman untuk memastikan kinerja yang tepat. Mirip dengan instrumen elektronik yang membutuhkan suhu kerja tertentu di mana mereka dapat beroperasi dengan baik, kondisi termal yang tidak cocok akan mempengaruhi fisiologi atau psikologi individu (Fang, Clausen, \& Fanger, 1998). Secara alami kenyamanan termal adalah masalah subyektif, maka setiap kondisi lingkungan termal yang dikategorikan nyaman oleh individu dapat berbeda dengan persepsi orang lain. Standar untuk kondisi lingkungan termal untuk hunian manusia (ASHRAE, 2013) menyatakan bahwa suhu dan kelembaban udara adalah parameter utama dalam menentukan kenyamanan termal, bersama dengan tingkat metabolisme, isolasi pakaian, suhu radiasi dan kecepatan udara.

Ketidaksesuaian kondisi ruang dengan mengakibatkan efek pada kinerja individu dalam ruang tersebut. Pada daerah beriklim tropis, ketidaksesuaian dengan persyaratan kenyamanan termal terjadi karena ruangan memiliki temperatur yang lebih tinggi dibandingkan persyaratan. Ketidaksesuaian tersebut berarti tidak tercapainya kualitas lingkungan hidup dapat mengakibatkan menurunnya kualitas kerja, kualitas pembelajaran, ataupun kualitas hidup sehat; bergantung dari tujuan penggunaan ruangan tersebut. Karena itu, evaluasi kesesuaian suatu ruang dengan persyaratan kenyamanan termal perlu dilakukan untuk menghindari menurunnya kinerja individu yang beraktivitas dalam ruang tersebut.

Dalam tulisan ini, akan disajikan suatu hasil evaluasi kondisi ruang kelas berdasarkan kondisi termalnya. Baku mutu tentang kondisi termal ruangan yang diacu dalam tulisan ini adalah suatu regulasi persyaratan kenyamanan termal.

Metode yang digunakan dalam evaluasi adalah pengukuran langsung di dalam ruang kelas yang sedang digunakan dalam kegiatan belajar-mengajar. Analisis dilakukan 
berdasarkan perbandingan antara hasil pengukuran lapangan dengan baku mutu. Kesesuaian akan menjadi dasar untuk mencari peluang tindakan perbaikan yang dapat dilakukan pada ruangan tersebut. Sebaliknya, ketidaksesuaian yang terjadi akan menjadi dasar rekomendasi tindakan koreksi yang dapat dilakukan.

Hasil evaluasi ini bersifat unik karena merupakan hasil pengukuran lapangan pada ruang kelas yang efektif dipergunakan. Kondisi cuaca secara umum, kondisi struktur bangunan, serta aktivitas dalam ruangan menjadi faktor yang dipertimbangkan dalam analisis. Meskipun demikian, hasil analisis dapat dijadikan dasar pemikiran tidakan perbaikan dan/atau tindakan koreksi yang dapat dilakukan.

\section{DASAR TEORI}

Di Indonesia, acuan dalam penyediaan ruang yang sehat terkategori atas peruntukannya, yaitu untuk tempat kerja dan rumah tangga. Berdasarkan Keputusan Menteri Kesehatan, arahan dalam menyediakan kamar yang sehat di tempat kerja dan rumah tangga (Kemenkes, 2011, 2016), menyebutkan bahwa penting untuk menyediakan ruang di kantor dengan kisaran kelembaban relatif antara 30\% hingga $70 \%$ dan temperatur antara $23^{\circ} \mathrm{C}$ hingga $26^{\circ} \mathrm{C}$, sedangkan kualitas udara di rumah tangga berada dalam kisaran kelembaban relatif antara $40 \%$ hingga $60 \%$ dan temperatur antara $18^{\circ} \mathrm{C}$ hingga $30^{\circ} \mathrm{C}$ suhu. Dalam grafik psychrometric (seperti dalam Gambar 1), persyaratan untuk ruang di kantor dinyatakan dengan garis oranye sedangkan persyaratan untuk rumah tangga dinyatakan dengan garis hitam. Persyaratan ruang sehat ini akan menjadi dasar diskusi.

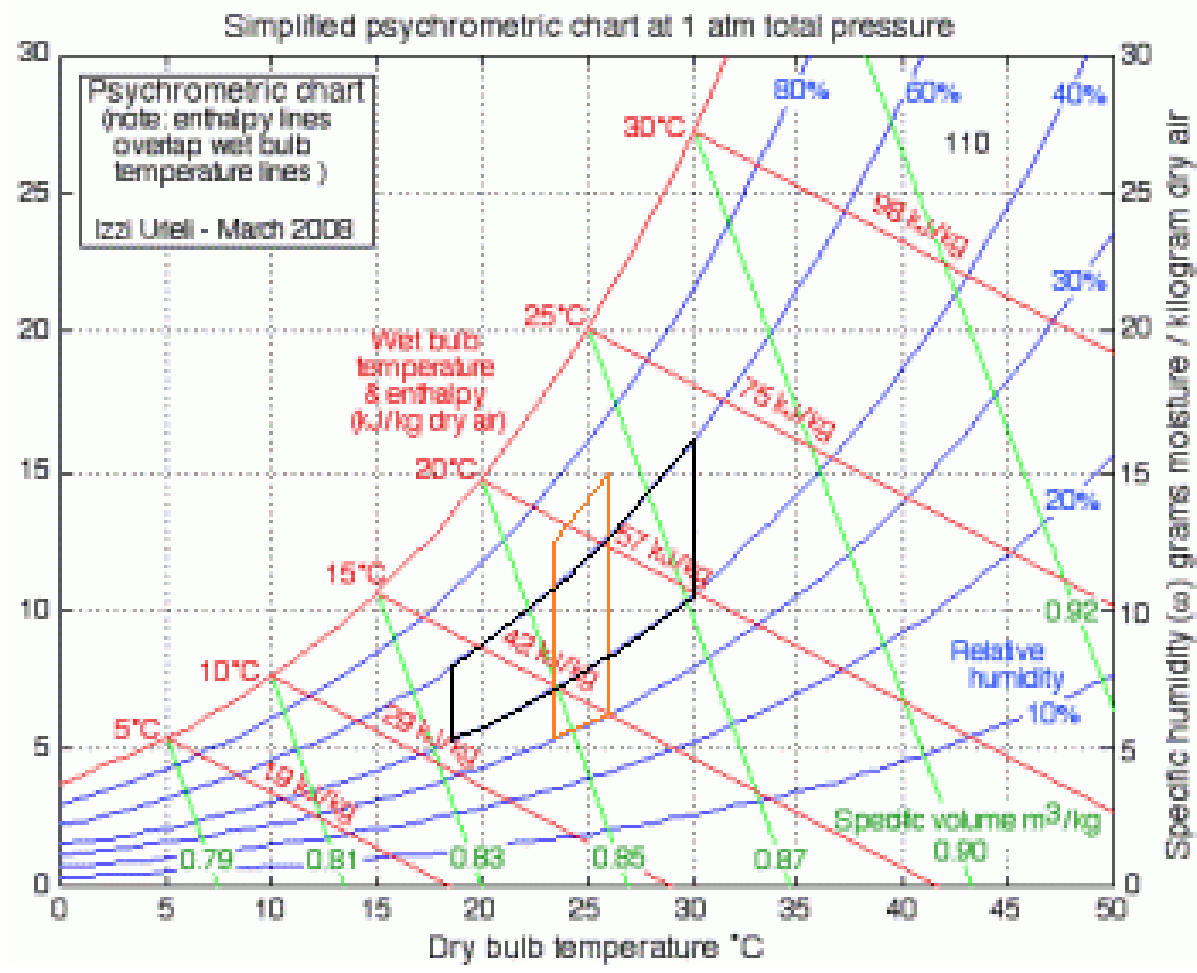

Gambar 1 Persyaratan termal berdasarkan regulasi Kemenkes dalam grafik psychrometric

Cuaca tropis dapat menjadi salah satu sebab tidak sesuaianya kondisi ruangan dengan persyaratan termal. Kecenderungan untuk mendapati ruangan dengan temperatur lebih tinggi sangat dimungkinkan. Cuaca, seperti halnya olah raga dapat menimbulkan efek dehidrasi yang berujung pada heat stress. Kegiatan yang berbasis kinerja otak seperti halnya kemampuan aritmatika, memori jangka pendek, dan kemampuan visual- motorik dapat mengalami penurunan kinerja yang disebabkan oleh dehidrasi (Gopinathan, Pichan, \& Sharma, 1988). Kinerja otak lain juga dapat mempengaruhi kemampuan dalam membaca dan dalam memahami bacaan (Wyon, 1970). Jadi, heat stress dalam ruangan dengan kondisi termal yang tidak sesuai dapat mengakibatkan efek pada siswa perguruan tinggi, baik yang berada dalam jalur peminatan 
teknik maupun sosial. Kedua kajian terdahulu tersebut, menekankan pengaruh heat stress atau temperatur dalam observasi.

Disisi yang lain, standar (ASHRAE, 2013) telah mengatakan bahwa dalam mendefinisikan persyaratan termal enam variabel, yaitu laju metabolisme, pakaian, kecepatan angin, temperatur radiasi, temperatur udara dan kelembaban, perlu diperhatikan. Meskipun demikian, mengacu pada regulasi Kemenkes, temperatur udara dan kelembaban adalah faktor yang menentukan. Selain itu, kedua besaran tersebut adalah besaran yang langsung dapat dirasakan oleh individu yang berada dalam ruangan. Karena itu, dalam evaluasi ini, hanya dua faktor terakhir tersebut yang akan diukur secara langsung dalam ruangan.

\section{METODE PENGUKURAN}

Seluruh pengukuran dilakukan dengan menggunakan data logger temperatur dan kelembaban yang berurutan memiliki akurasi $0,05^{\circ} \mathrm{C}$ dan $0,1 \%$. Pengukuran dilakukan dalam empat ruangan yang berbeda. Tiga ruangan diantaranya (A, B, dan $\mathrm{C}$ ) memiliki dimensi panjang $\mathrm{x}$ lebar $\mathrm{x}$ tinggi yang hampir serupa yaitu sekitar $5 \mathrm{~m} \times 7 \mathrm{~m} \times 3 \mathrm{~m}$. Ketiga ruangan tersebut berada dalam gedung tidak permanen berlantai satu dengan dinding dan plafon terbuat dari papan duplek dan atap yang terbuat dari asbes. Sedangkan ruangan keempat (D) berada di tengah gedung permanen dan tidak terkena sinar matahari.

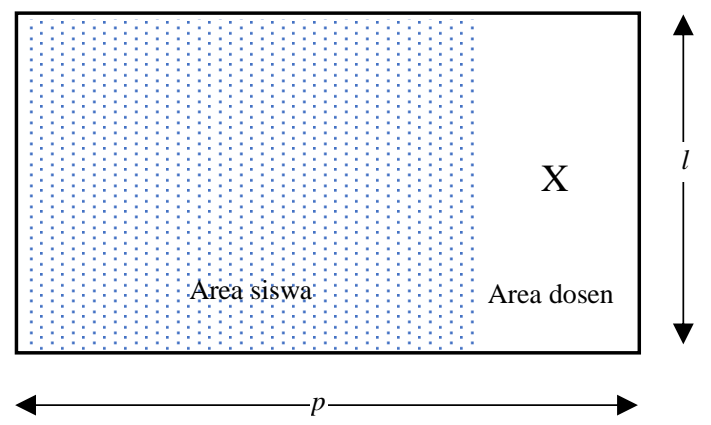

Gambar 2 Skema pengukuran

Keempat ruangan dilengkapi dengan satu unit refrigerator berkapasitas $4 \mathrm{pk}$ sebagai pendingin ruangan. Dalam kondisi kegiatan belajarmengajar terdapat sekitar 25 orang dosen dan siswa yang berada dalam ruangan yang berperan sebagai sumber panas. Selain manusia sebagai sumber panas, terdapat satu unit proyektor yang bekerja selama pengukuran dilangsungkan.
Pada saat kegiatan belajar-mengajar, ruangan terbagi menjadi dua; dua pertiga bagian kelas merupakan area siswa berada dan sisanya merupakan area dosen. Pengukuran dilakukan pada satu titik yang berada ditengah area dosen sedemikian sehingga tidak terpengaruh langsung oleh panas yang dihasilkan oleh proyektor ataupun oleh individu dalam ruangan.

Skema pengukuran dalam ruangan ditampilkan dalam Error! Reference source not found.. Dengan $p$ adalah panjang ruangan sekitar $7 \mathrm{~m}, 1$ adalah lebar ruangan sekitar $5 \mathrm{~m}$ dan $\mathrm{x}$ adalah titik pengukuran yang berada ditengah area dosen.

Untuk meminimalkan variasi cuaca, pengukuran ketiga dilakukan pada ruang $\mathrm{C}$ dan dilakukan pada hari yang sama dengan pengukuran pada ruang A dan B. Pengukuran dilakukan secara hampir kontinyu selama sembilan jam antara pukul 08.00 sampai dengan pukul 18.00. Pengukuran dilakukan di tiga segmen waktu yaitu pagi (di ruang A antara pukul 08.00 sampai 11.00), siang (di ruang B antara pukul 12.00 sampai 15.00 ) dan sore (di ruang $C$ antara pukul 15.00 sampai 18.00). Pengukuran di ruang $\mathrm{D}$ dilakukan sebagai pembanding dan dilakukan antara pukul 18.30 sampai 21.00.

\section{HASIL DAN PEMBAHASAN}

Hasil pengukuran temperatur dan kelembaban pada ruang $\mathrm{A}, \mathrm{B}, \mathrm{C}$, dan D ditampilkan secara berurutan dalam Gambar 3, Gambar 4, Gambar 5, dan Gambar 6.

Pengukuran pertama dilakukan di ruang A dengan hasil pengukuran temperatur dan kelembaban yang terdapat dalam Gambar 3. Gambar 3 menunjukkan bahwa kenaikan temperatur sampai pukul 09.00 tidak lebih dari $0,5^{\circ} \mathrm{C}$. Akan tetapi, semakin siang temperatur ruang semakin tinggi. Kenaikan ini dapat terjadi karena penas yang dihasilkan dalam ruang dan disipasi panas dari luar ruang. Observasi mencatat bahwa sejak pukul 08.30 kelas telah terisi penuh dengan siswa, tetapi kenaikan temperatur sampai pukul 09.00 tidak signifikan. Selain itu observasi juga mencatat bahwa hari pada saat pengukuran dilakukan sangat cerah tidak berawan. Hal ini menunjukkan bahwa temperatur ruang lebih dipengaruhi oleh disipasi panas dari luar ruangan, karena pemanasan alami 
matahari, dibandingkan pembangkitan panas oleh individu dalam ruangan.

Pengukuran kedua dilakukan di ruang B yang memiliki karakteristik struktur serupa dengan ruang A. Di awal pengukuran, temperatur di ruang $\mathrm{B}$ dekat dengan temperatur di akhir pengukuran di ruan A, yaitu di sekitar $32^{\circ} \mathrm{C}$. Selanjutnya, temperatur di ruang $\mathrm{B}$, memiliki kecenderungan naik mengikuti trend pada pengukuran di ruang A sampai dengan sekitar pukul 12.30. Setelah itu sampai dengan pukul 15.00 , temperatur ruang cenderung untuk stabil di sekitar nilai $33^{\circ} \mathrm{C}$.

Pengukuran kelembaban pada kedua ruangan menunjukkan hasil yang sangat berbeda. Rata-rata kelembaban pada ruang A selama pengukuran adalah $39 \%$ sedangkan pada ruang $\mathrm{B}$ adalah 54\%. Hal ini dapat disebabkan perbedaan posisi kedua ruangan.

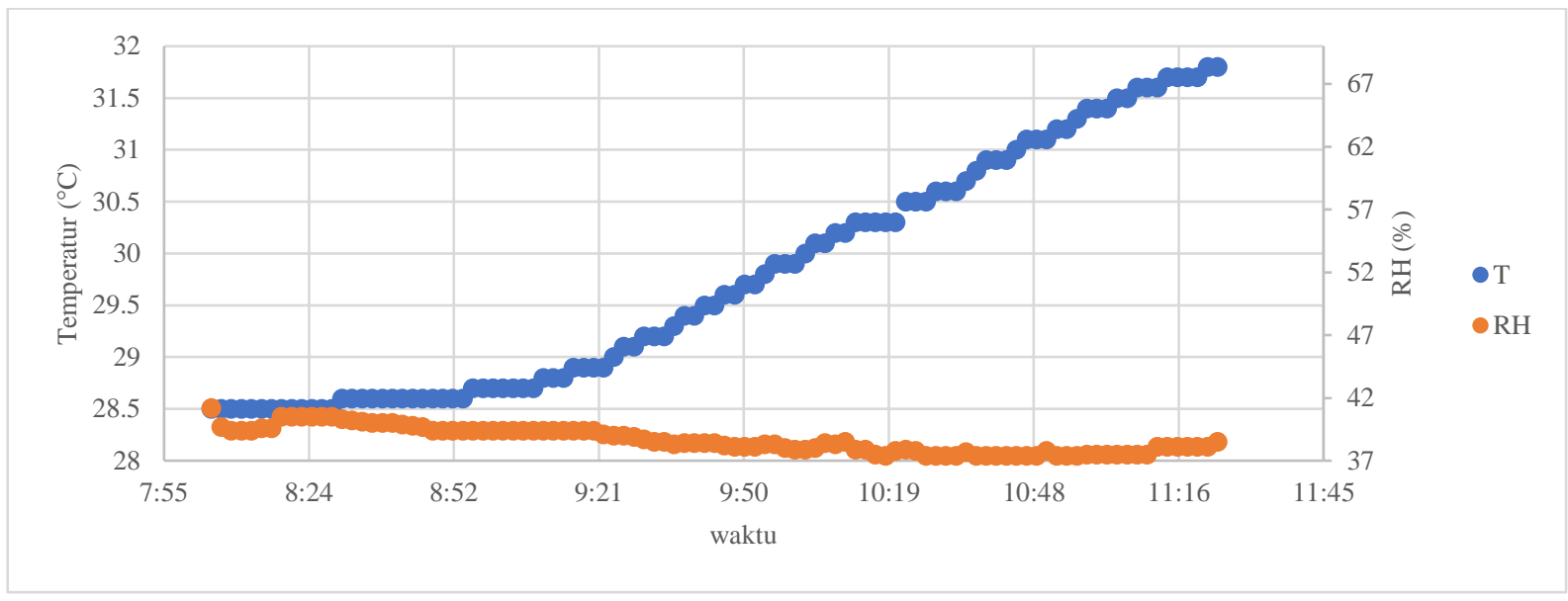

Gambar 3 Hasil pengukuran pada ruang A



Gambar 4 Hasil pengukuran pada ruang $B$

Hasil pengukuran temperatur dan kelembaban pada ruang $\mathrm{C}$ dapat dilihat pada Gambar 5.

Gambar 5 menunjukkan bahwa di awal pengukuran, temperatur ruang $\mathrm{C}$ sangat dekat dengan temperatur di akhir pengukuran di ruang $\mathrm{B}$, yaitu di sekitar $33^{\circ} \mathrm{C}$. Hal ini mengindikasikan bahwa ketiga ruangan $(\mathrm{A}, \mathrm{B}$, dan $\mathrm{C}$ ) memiliki kondisi temperatur yang hampir serupa. Sampai pukul 17.00, temperatur ruang $\mathrm{C}$ memperlihatkan kondisi yang stabil, lalu menurun sampai dengan akhir pengukuran. Penurunan wajar terjadi karena intensitas matahari mulai menurun di sore hari setelah pukul 15.00.

Berbeda dengan perbandingan antara kelembaban ruang $\mathrm{A}$ dan $\mathrm{B}$, pengukuran kelembaban di ruang $\mathrm{C}$ menunjukkan nilai yang hampir sama dengan kelembaban di ruang $\mathrm{B}$ yaitu di sekitar $51 \%$ s.d $53 \%$. 


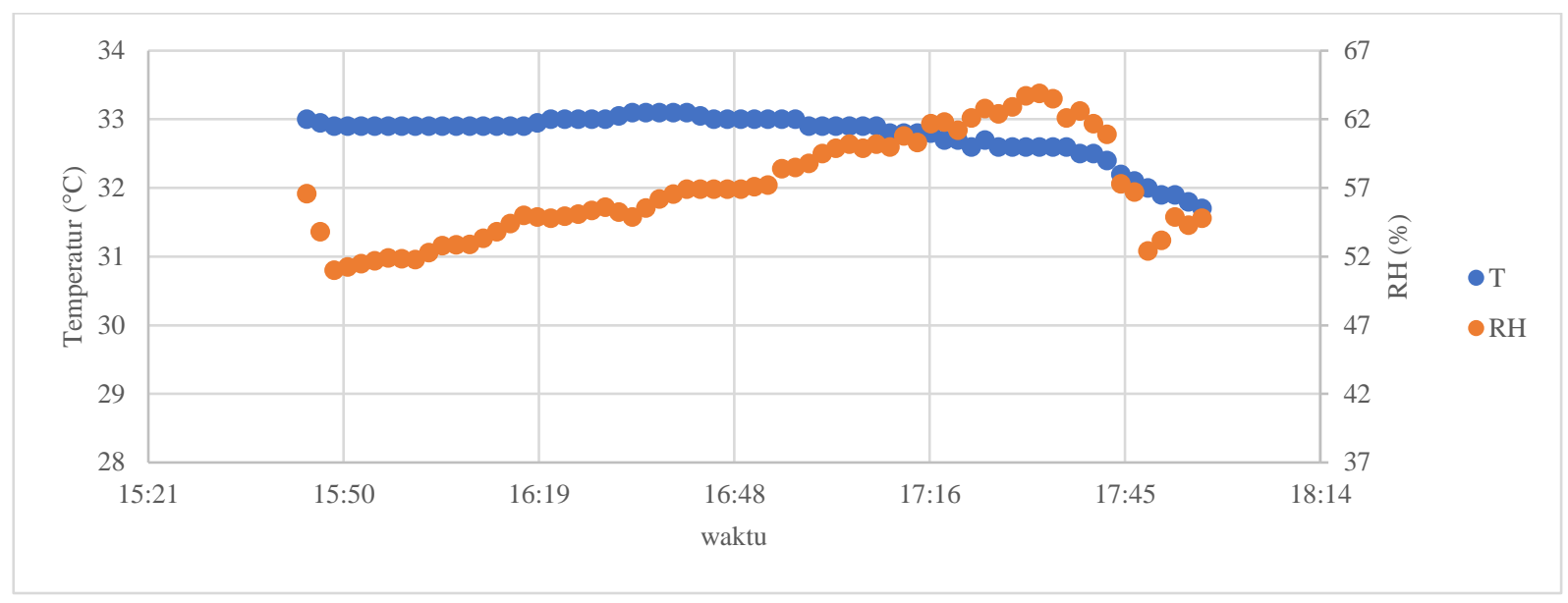

Gambar 5 Hasil pengukuran pada ruang $C$

Pengukuran keempat dilakukan untuk perbandingan dalam evaluasi kualitas udara. Pengukuran keempat dilakukan di ruang D yang memiliki karakteristik struktur berbeda dari ruang $\mathrm{A}, \mathrm{B}$ dan $\mathrm{C}$. Bila ketiga ruangan tersebut berada dalam gedung tidak permanen, maka ruang D berada di lantai lima suatu gedung permanen berlantai tiga belas dan berada di tengah-tengah gedung. Karena sama sekali tidak terekspose matahari, maka radian temperatur dapat diabaikan. Karena itu, pengukuran dilakukan di malam hari pada rentang anatara pikul 18.30 sampai 21.00. Hasil pengukuan temperatur dan kelembaban di ruang D dapat dilihat pada Gambar 6. Gambar 6 menunjukkan bahwa pada ruang dengan karakteristik struktur yang dimiliki ruang $\mathrm{D}$, nilai temperatur dan kelembaban dapat dipertahankan dalam kondisi hampir stabil.

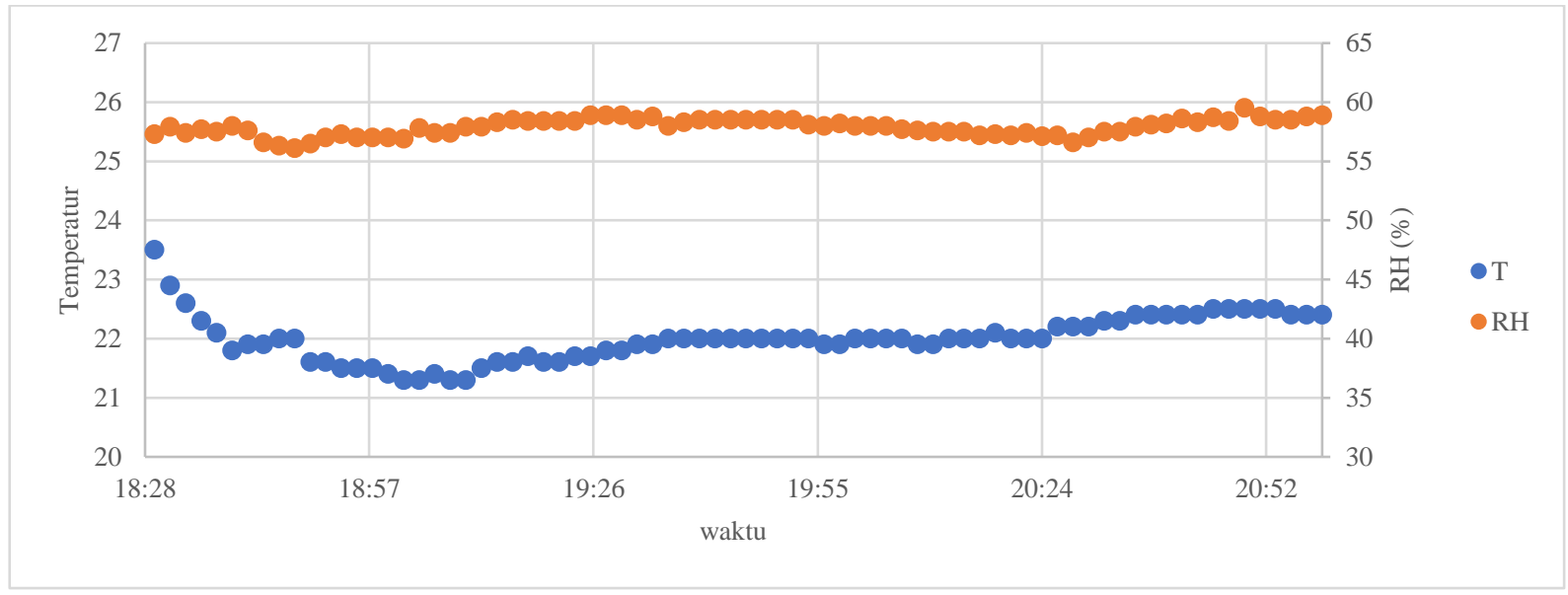

Gambar 6 Hasil pengukuran pada ruang D

Untuk melihat kesesuaian kondisi ruangan dengan persyaratan kualitas udara, maka digunakan nilai maksimum dan minimum dari pengukuran temperatur dan kelembaban di setiap ruangan, seperti yang terdapat dalam Tabel 1 . Kemudian untuk setiap nilai maksimum dan minimum, pasangan nilai temperatur dan kelembaban tersebut di letakkan dalam grafik psychrometric yang disederhanakan seperti dalam Gambar 7. Baku mutu yang dipakai adalah persyaratan udara untuk ruang kerja yaitu kelembaban antara 30\% hingga $70 \%$ dan temperatur antara $23^{\circ} \mathrm{C}$ hingga $26^{\circ} \mathrm{C}$.

Tabel 1 Nilai maksimum dan minimum pengukuran temperatur dan kelembaban

\begin{tabular}{|l|r|r|r|r|}
\hline Ruang & \multicolumn{2}{|c|}{$\begin{array}{c}\text { Temperatur } \\
\left({ }^{\circ} \mathrm{C}\right)\end{array}$} & \multicolumn{2}{c|}{$\begin{array}{c}\text { Kelembaban } \\
(\%)\end{array}$} \\
\hline & \multicolumn{1}{|c|}{ maks } & min & maks & \multicolumn{1}{c|}{ min } \\
\hline Ruang A & 31,8 & 28,5 & 41,2 & 37,4 \\
\hline Ruang B & 33,3 & 31,8 & 57,4 & 52,5 \\
\hline Ruang C & 33,1 & 31 & 63,9 & 51 \\
\hline Ruang D & 26 & 21,3 & 59,8 & 55,2 \\
\hline
\end{tabular}


Dalam Gambar 7, terdapat dua kotak yang mengindikasikan persyaratan kualitas udara di tempat kerja (kotak berwarna hitam) dan yang mengindikasikan persyaratan kualitas udara di rumah (kotak warna kuning). Bila pengukuran pada keempat ruangan diletakkan dalam gambar tersebut maka terlihat bahwa kondisi ruang A, B dan $\mathrm{C}$ (diindikasikan oleh titik berwarna merah) berada di luar persyaratan. Hanya kondisi ruang D yang dapat memenuhi persyaratan. Hal ini menunjukkan bahwa penggunaan konstruksi gedung tidak permanen untuk kegiatan belajar mengajar tidak dapat memenuhi persyaratan kualitas udara.

Posisi titik merah pada Gambar 7, mengindikasikan bahwa letak titik berada diluar daerah persyaratan lebih dikarenakan temperatur yang tinggi, yaitu $2,5^{\circ} \mathrm{C}$ s.d $7,3^{\circ} \mathrm{C}$ diatas persyaratan, sedangkan kelembaban sesuai dengan persyaratan. Temperatur ruang berada
Karena itu ada dua tindakan koreksi yang dapat dilakukan untuk menggeser titik-titik tersebut untuk masuk kedalam daerah persyaratan.

Tindakan koreksi yang pertama adalah dengan mengubah struktur gedung tempat ruang berada dari kondisi tidak permanen menjadi permanen. Tindakan ini dapat dilakukan dengan sasaran mengendalikan disipasi panas dari luar gedung. Selain itu dapat meningkatkan keamanan gedung tersebut. Akan tetapi tindakan koreksi ini membutuhkan perencanaan yang lama dengan anggaran yang tidak sedikit.

Tindakan koreksi yang kedua adalah dengan meningkatkan kapasitas sistem refrigerasi yang terdapat dalam ruang. Dengan kapasitas yang tepat maka temperatur dapat diturunkan serta kelembaban dapat dikendalikan. Keuntungan dari tindakan ini adalah penyelesaian masalah yang lebih cepat dengan biaya yang lebih rendah, akan tetapi, dengan biaya operasional sistem refrigerasi yang meningkat.

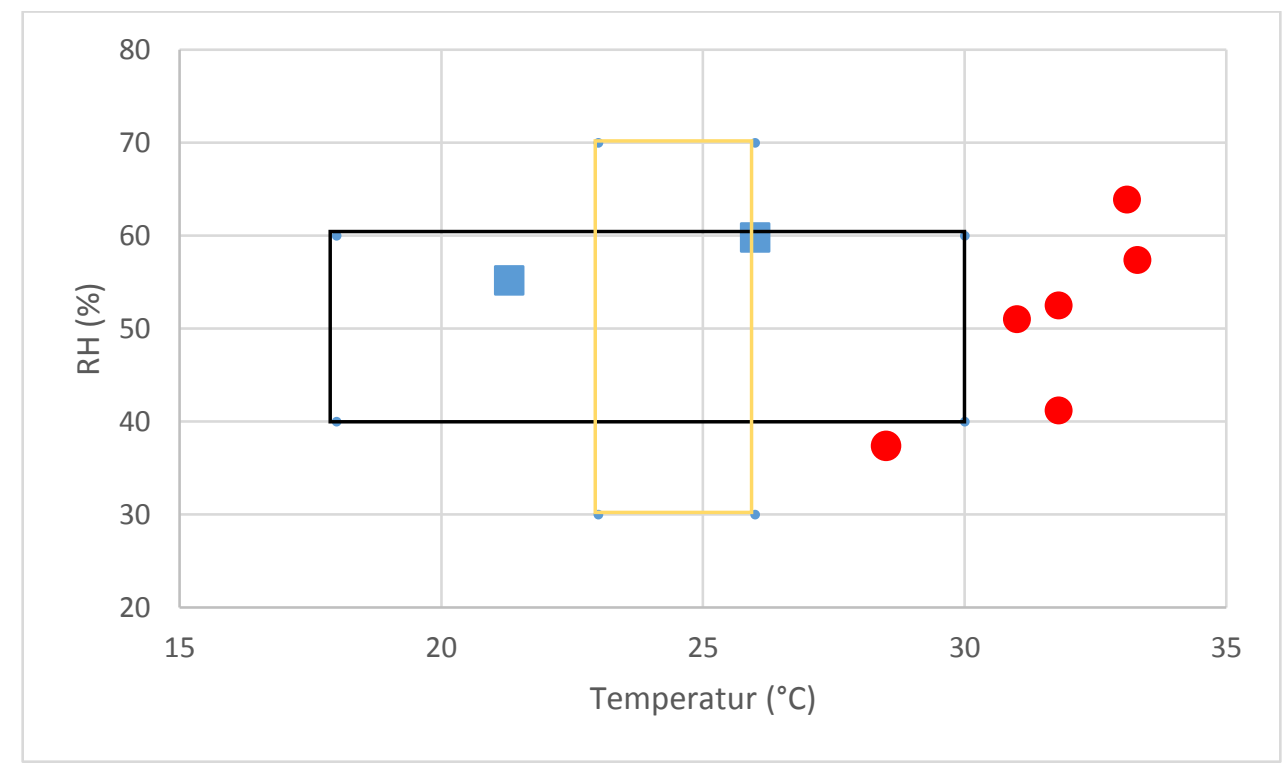

Gambar 7 Perbandingan dengan persyaratan

\section{KESIMPULAN}

Dari pembahasan atas hasil pengukuran temperatur dan kelembaban di ruang kuliah, didapati bahwa seluruh ruangan dengan karakteristik struktur tidak permanen, memiliki kondisi udara yang tidak sesuai dengan persyaratan karena temperatur ruang berada $2,5^{\circ} \mathrm{C}$ s.d $7,3^{\circ} \mathrm{C}$ diatas persyaratan. Sementara itu, kondisi kelembaban masih dalam batas yang diperbolehkan oleh persyaratan. Dengan kondisi tersebut, tindakan korektif yang lebih feasible untuk dilakukan adalah dengan meningkatkan efektivitas pengkondisian udara ruangan.

\section{DAFTAR PUSTAKA}

ASHRAE, A. (2013). Standard 55-2013, Thermal comfort Conditions for Human Occupancy, ASHRAE. Atlanta. 
Fang, L., Clausen, G., \& Fanger, P. O. (1998). Impact of temperature and humidity on the perception of indoor air quality. Indoor Air, 8(2), 80-90.

Gopinathan, P., Pichan, G., \& Sharma, V. (1988). Role of dehydration in heat stress-induced variations in mental performance. Archives of Environmental Health: An International Journal, 43(1), 15-17.

Peraturan Menteri Kesehatan No. 1077 tentang Pedoman Penyehatan Udara Dalam Ruang Rumah (2011).

Peraturan Menteri Kesehatan No. 48 tahun 2016 tentang Standar Keselamatan dan Kesehatan Kerja Perkantoran (2016).

Wyon, D. (1970). Studies of children under imposed noise and heat stress. Ergonomics, 13(5), 598-612. 